\title{
Rádio Educativa do Piauí: a Serviço de Quê e de Quem?
}

\section{Maria das Graças Targino}

\section{Antônio Teixeira de Barros}

Universidade Federal do Piauí (UFPI)

Analisa a Rádio Educativa do Piauí (REPI) mediante o estudo de sua audiência, tipo de público-ouvinte, programação e conteúdo educativo e formas de falseamento da informação radiofônica, na perspectiva da Teoria Crítica, buscando, ainda, contextualizar a radiodifusão educativa no panorama da radiodifusão brasileira.

\section{Introdução}

Consensualmente, um país como o Brasil, cujos índices de analfabetismo são propalados a cada dia, necessita, com urgência, atingir níveis mínimos de instrução, de formação e de socialização, ainda que, tanto pela extensão continental e pelas peculiaridades regionais e estaduais, como pelos escassos recursos destinados à educação pelos governos, enfrente sérias restrições para a execução dessa tarefa, de forma direta. Neste sentido, o rádio surge como o elemento mais acessível e de maior amplitude. E o rádio educativo, visualizado como meio que veicula, fundamentalmente, conteúdos práticos para a vida das pessoas, possibilitando-lhes o conhecimento e a transformação do mundo, se

Este trabalho contou com a colaboração das seguintes pessoas: Ana Cristina de Souza Batista, Catmem Cilene Teixeira, e Maria Aparecida Oliveira, na coleta de dados; Maria do Rosário Teixeira de Barros, na gravação dos programas, e Tony, na confecção de tabelas e gráficos. 
fortalece, então, como fulcro no processo desenvolvimentista do País, dos Estados e dos municípios.

Assim, a Rádio Educativa do Piauí (REPI), emissora do governo do Estado, ocupa ou deveria ocupar um espaço significativo no panorama da radiofonia piauiense. Avaliar sua atuação significa avaliar seu papel na radiodifusão educativa. $\mathrm{O}$ caráter educativo, aqui, não se confunde com acúmulo de conhecimentos inúteis, nem com educação formal. A fonte principal de conhecimento é o próprio povo e a participação popular não é apenas engodo para ganhar audiência, mas a razão de ser da emissora. O objetivo principal do rádio educativo, como diz Vigil (1986), não é domesticar nem manipular o povo, mas aumentar seu nível de conscientização e fortalecer suas organizações.

Nesse contexto e compreendendo a audiência como o conjunto de pessoas que, em dado momento, ouvem uma emissão de rádio ou assistem a um programa de televisão, este trabalho objetiva identificar o índice de audiência da REPI, a fim de estimá-lo, quantitativamente, no perímetro urbano - bairros adjacentes, centro, periferia - de Teresina, no Estado do Piauí, bem como caracterizar seu público, sob diferentes aspectos. Pretende, ainda, apontar os programas de maior receptividade e os motivos que concorrem para isso; avaliar o conteúdo educativo da programação e analisar as formas de falseamento ou encobrimento das notícias.

Um estudo de audiência da REPI justifica-se pela suposição de que, por seu vínculo estatal,está ela propensa a uma maior incidência de manipulação do conteúdo das mensagens veiculadas de que trata Marcondes Filho (1989). Por outro lado, registra-se a carência de trabalhos científicos sobre a audiência de emissoras de rádio no Piauí, o que pode fazer com que os resultados desta pesquisa sirvam de subsídios à elaboração de futuros trabalhos ou atuem como diagnóstico aos administradores da REPI, favorecendo a interveniência da universidade em temas de interesse comunitário.

Visando à consecução dos objetivos propostos, de início apresentamse informações sobre o rádio em geral e o rádio educativo, em particular, 
abordando-se, em seguida, as formas de falseamento da informação. Seguem o detalhamento do material e dos métodos empregados e a discussão dos resultados. Ao final, estão as conclusões, complementadas por recomendações e a bibliografia consultada.

\section{Rádio}

FUNÇÕES E PRINCÍPIOS

Na opinião da Comissão Internacional para o Estudo dos Problemas da Comunicação (1983), em todas as regiões do mundo, o rádio é o meio de comunicação social mais difundido, ainda que, não comprovadamente, o mais poderoso. Nenhum outro alcança um número tão grande de pessoas, visando à informação, ao ensino e ao entretenimento. Em 1983, estimavase em um bilhão o número de receptores de rádio no mundo inteiro, o que corresponde à média de um para quatro pessoas.

No Brasil, com 30.702 .633 analfabetos ( $21,01 \%$ da população), se a grande maioria não desenvolveu o hábito de leitura, $70 \%$ da população rural ouve rádio e, na zona urbana, este índice chega a $95 \%$ (Ortriwano, 1985). Para esse autor, o Brasil segue os Estados Unidos e ocupa o segundo lugar no âmbito mundial, quanto ao número de emissoras instaladas. O Piauí, reconhecidamente um Estado carente, representa um bom exemplo: possui 47 estações de rádio, 37 no interior e 10 em Teresina (Fundação IBGE, 1991).

No entanto, mais importante que quantificar é discutir, até que ponto, superando as barreiras da leitura e da escrita, apoiado, fundamentalmente, na oralidade, o rádio tem colaborado na formação dos indivíduos, ainda que estes possuam pouca ou nenhuma instrução formal. Para Lage (1987), a oralidade da linguagem radiofônica constitui herança da retórica medieval, quando as informações disponíveis ao povo vinham sob a forma de decretos, proclamações, exortações e sermões. Prado (1989) ressalta que além dessa capacidade de se comunicar com um público 
heterogêneo e dispensar uma formação específica para a decodificação das mensagens, o rádio possibilita, por meio de reportagens, entrevistas, mesas-redondas etc, o aprofundamento e a reflexão das questões sociais.

Fontecilla (1983) identifica e desdobra as funções básicas do rádio:

a) função informativa - a informação como um dos elementos que permite ao homem ajustar-se ao mundo exterior, de forma legítima e coerente, conquistando o status de cidadão. As mensagens informativas agrupam-se em quatro áreas:

-área jornalística - emissão de notícias - fatos que têm interesse social, nos níveis local, regional, nacional e internacional;

-área publicitária - divulgação de produtos e serviços de interesse público;

-área utilitária ou de serviços - transmissão de avisos, recados, pedidos, ainda que de interesse restrito a grupos ou indivíduos; -área documentária - narração de temas específicos no contexto da atualidade;

b) função educativa - a educação como instrumento que propicia às massas populares desvendar a realidade objetiva, transformando-a quanto mais se "inserem nela criticamente" (Freire, 1988). As mensagens educativas dividem-se em quatro áreas: -área documentária - com forma de apresentação similar à informativa, pretende, além de informar, contribuir para a instrução formal, explorando temas relacionados com a cultura em geral e com a vida cotidiana;

-área cultural - trasmissão dos valores culturais, visando à formação pessoal e social do público- ouvinte;

-área de ensino extra-escolar - programação extracurricular em extensão agrícola, ecologia, educação sanitária, sindicalismo e política; -área instrucional - divulgação de programas segundo o sistema oficial de ensino;

c) função recreativa - considera o lazer essencial à vida das pessoas, ao reduzir suas tensões e o stress diários. Tal função desmembra-se em: 
-área musical - difusão de músicas de vários tipos, programas de auditório, festivais de música etc;

-área novelística — apresentação de novelas, poesias, contos etc;

-área humorística - transmissão de comédias, piadas, festas, jogos.

Consciente do papel relevante que o rádio pode desempenhar, ao assumir, integralmente, essas funções, Porchat (1989) acentua que a transmissão radiofônica exige uma linguagem "correta, nítida, simples, rica, repetitiva, forte, concisa, invocativa e agradável".

Fontecilla (1983) sintetiza esses princípios da linguagem radiofônica:

A redundância, repetição sistemática e estratégica das informações, busca amenizar a fugacidade intrínseca a qualquer forma de linguagem oral e vencer a "concorrência" dos elementos ambientais externos, tais como ruídos, falas e gritos.

A linguagem direta, em que se privilegia a estrutura própria da linguagem coloquial — sujeito, predicado e complemento — , pretende facilitar a assimilação das mensagens, pois, sem dúvida, é de maior compreensão.

Quanto ao uso correto da pontuação (o uso da vírgula e do ponto), as regras gramaticais de pontuação nem sempre se aplicam à radiofonia, devido ao efeito dos silêncios, pausas e prolongamentos dos sons. No caso da vírgula, evita-se a intercalação de frases, pois isto causa distanciamento sonoro do sujeito ou agente da mensagem. O ponto serve para separar as idéias, o que dá agilidade ao texto e facilita a percepção. Em muitos casos, nos scripts, usa-se o ponto em vez da vírgula, para maior clareza, força e ritmo, o que já funciona como estímulo à audição.

A motivação/antecipação consiste em manter a atenção do ouvinte, antecipando-lhe alguns dos elementos que serão transmitidos. Essa antecipação, no entanto, deve ser estratégica, pois se tudo for antecipado, sem criar expectativas, obtém-se o efeito contrário, cerceando a motivação.

RÁDIO NO BRASIL: BREVE HISTÓRICO

No Brasil, é indiscutível a importância do rádio na história da imprensa. 
Na década de 20, foi ele o principal veículo de propagação de informações. Autores como Ortriwano (1985) expõem, detalhadamente, as transformações que o rádio sofre, a partir da Revolução de 30. A forte centralização do poder executivo, exercido por Getúlio Vargas, e o desenvolvimento do comércio e da indústria favorecem a expansão da radiodifusão. O rádio se impõe como elemento de grande importância política. Veicula propagandas ideológicas, como na Revolução Constitucionalista de 1932. Oferece programas políticos. O governo federal cria o Departamento Oficial de Propaganda (DOP), mais tarde Departamento de Imprensa e Propaganda (DIP), criando, então, a "Voz do Brasil". A implantação da Rádio Nacional, em 1940, consolida esse projeto de sustentação política e se impõe como modelo para a radiofonia de então.

Mas o rádio também se impõe como elemento de importância econômica, estimulando o consumo e, como decorrência, a indústria e o comércio. O uso crescente de comerciais (os "reclames") concorrem para transformar o rádio de instrumento erudito, educativo e cultural em força popular, com ênfase no lazer, surgindo, em 1935, o primeiro programa de auditório, na Rádio Kosmos, em São Paulo. Lopes (1990) afirma que foi o rádio, ao lado do cinema, o meio que, nesse período, possibilitou às classes populares as primeiras vivências cotidianas da nação, difundindo a experiência cultural simultaneamente partilhada por nordestinos, nortistas e sulistas.

O rádio chega nos anos 40, a denominada "época de ouro", estruturado como empresa. As emissoras concorrem entre si por maior audiência e maior faturamento, favorecendo a criação do Instituto Brasileiro de Opinião Pública e Estatística (IBOPE). É a década da primeira radionovela. É o início da especialização do rádio em campos específicos, como os esportes. É o fortalecimento do radiojornalismo como atividade mais estruturada: o "Repórter Esso", na Rádio Nacional, impera por 27 anos, como "testemunha ocular da história".

A "época de ouro" termina com o surgimento da televisão brasileira, que recruta do rádio profissionais, quadros, idéias e a publicidade. Mas 
é a eletrônica que permite ao rádio reagir. O transistor possibilita o uso do rádio em qualquer lugar e a qualquer hora, bem como incentiva uma comunicação mais ágil, menos onerosa, em substituição às produções caras, com grandes equipes técnicas. Acentuam-se, então, nos anos 50, a produção de programas especializados e o radiojornalismo.

$\mathrm{Na}$ década de 60 , os serviços de utilidade pública e a programação "música, exclusivamente música" tomam impulso. É a época das primeiras emissoras em freqüência modulada (FM), que na década de 70 se expandem, mantendo, sempre, o gênero musical. Ao lado dessa tendência, intensificam-se as reportagens de rua, visando resgatar a relação dialógica rádio-ouvinte. A propensão à especialização cresce em busca de audiência nos diversos segmentos sociais, por meio de emissões heteróclitas para as várias faixas etárias, em diferentes horários. Ainda nos anos 70, surgem as agências de produção radiofônica, registrando-se uma forte inclinação para a formação de redes e a regionalização da grade de programas.

$\mathrm{Na}$ verdade, essas últimas décadas do rádio brasileiro são marcadas pela evolução dos meios eletrônicos: o disco laser; a transmissão por ondas médias com som estéreo; os sistemas de comunicação por satélite em transmissões radiofônicas nacionais e internacionais. São esses aperfeiçoamentos tecnológicos que têm possibilitado à radiofonia continuar sendo o sistema de distribuição de mensagens mais amplo, rápido e econômico de que dispõe a sociedade. Se a atualidade e a rapidez da difusão são essenciais ao processo de transferência da informação, os elementos precípuos da tecnologia radiofônica — simultaneidade e instantaneidade - são básicos para esse processo. Prado (1989) lembra que a televisão, com características similares, demanda o deslocamento de equipes técnicas que devem atender à simultaneidade e à instantaneidade, o que faz com que o rádio continue como o meio mais rápido. 


\title{
Rádio Educativo
}

\author{
BREVE HISTÓRICO
}

O sistema de rádio educativo é resultado das experiências em teleducação - educação mais comunicação de massa - iniciadas na Europa e nos Estados Unidos, no começo deste século, com os primeiros estudos por correspondência, para melhor qualificação profissional. Utilizado, de início, dentro da escola, como apoio à instrução formal, somente na década de 40, no Canadá, é que o rádio se impõe como veículo de educação a distância, com o "rádio-fórum", direcionado a comunidades rurais.

De acordo com Siqueira, Freitas e Haddad (1989, p.359), o final dos anos 60 marca o auge da teleducação como "proposta redentora de 'carências educacionais'" para nações subdesenvolvidas ou em desenvolvimento, ainda que autores como Bordenave (1987) declarem que a teleducação brasileira se inicia em 1923, com a ação pioneira de Roquette Pinto. Este, ao lado de Henrique Morize e de outros membros da Academia Brasileira de Ciências, funda a Rádio Sociedade do Rio de Janeiro, doada, depois, ao governo federal.

Ainda no Brasil, a exemplo do que ocorreu na Colômbia, em Sutatenza, onde foi criada, por iniciativa do padre Joaquim Salcedo, em 1947, a primeira escola radiofônica da América Latina, a Igreja Católica adere à teleducação, instituindo, no final da década de 50 e início da década de 60 , através da Conferência Nacional dos Bispos do Brasil, o "Movimento Brasileiro de Educação de Base (MEB)", primeira experiência de radiodifusão educativa a serviço da educação popular, sobretudo, no Nordeste, Norte e Centro-Oeste, com a alfabetização, segundo Bordenave (1987), de quase meio milhão de camponeses, entre 1962 e 1964.

Ao lado do MEB, várias instituições surgem no País, ainda na década de 60 , com o objetivo comum de prestar assistência educacional através de sistemas radioeducativos e teleducativos, como a Fundação Educacional Padre Landell de Moura, em Porto Alegre-RS, de caráter privado, e a 
Fundação Padre Anchieta, também de direito privado, ainda que vinculada à Casa Civil do Governo do Estado de São Paulo, em São Paulo-SP. No Nordeste, surge o Instituto de Radiodifusão Educativa da Bahia, fundação de direito privado ligada à Secretaria de Educação e Cultura do Estado da Bahia, em Salvador-BA.

No âmbito federal, independente de iniciativas isoladas, o estágio seguinte foi a utilização do rádio no ensino supletivo, formalizada pela Lei $n^{9}$ 5.692, de 11 de agosto de 197 1, e do Parecem ${ }^{9}$ 699/72, do Conselho Federal de Educação, minuciosamente analisados por Horta (1983).

De fato, tanto no ensino supletivo como em outras esferas, tanto no País, como em todas as demais nações da América Latina, o sistema de rádio educativo se expande. Essa expansão conduz à fundação da Associação Latino-Americana de Educação Radiofônica (ALER), com sede em Quito, Equador. A ALER congrega cerca de 47 instituições de 21 países com um público estimado em 2 milhões de pessoas.

Entretanto, em termos nacionais, a eficiência dos veículos de teleducação sempre foi questionada por educadores e pesquisadores. Em uma avaliação do ensino supletivo através da radiodifusão, Siqueira, Freitas e Haddad (1989, p.361) afirmam que a análise da história da teleducação brasileira "evidencia uma ausência de coerência, coordenação e unificação" por parte do governo federal. Este cria, entre 1971 e 1981, seis instituições responsáveis pela teleducação, em nível nacional, todas subordinadas ao então Ministério da Educação e Cultura. São siglas diferentes para atribuições similares ou convergentes, o que gera conflitos, indefinição, não execução de planos ou questões insolúveis, como a que envolveu o cumprimento da Portaria Interministerial MEC/Minicom $\mathrm{n}^{9}$ 408/70, que determinava a transmissão gratuita de programas educativos nas emissoras comerciais de rádio e televisão, em cinco horas semanais. São denominações e siglas, como: Serviço de Radiodifusão Educativa (SRE), responsável pelo Projeto Minerva (1972 a 1981), um dos projetos de suplência de maior repercussão; Fundação Centro Brasileiro de Televisão Educativa (FCBTVE); Programa Nacional de Teleducação (PRONTEL); Departamento de Aplicações Tecnológicas (DAT); 
Secretaria de Aplicações Tecnológicas (SEAT) e FUNTEVÊ, que, mesmo mantendo a denominação de Fundação Centro-Brasileiro de Televisão Educativa, incorpora o SRE e a SEAT. Em 1988, a FUNTEVÊ é transferida do MEC para a Casa Civil da Presidência da República. A instalação da Empresa Brasileira de Radiodifusão (Radiobrás), no âmbito do então Ministério das Comunicações, gera conflito entre os dois ministérios, pelo controle das emissoras de rádio educativo.

Em face das reformas administrativas impostas pelo governo do Presidente Fernando Collor de Melo, com a extinção e a incorporação de ministérios e de órgãos, no âmbito da radiodifusão educativa, a FUNTEVÊ foi transformada na Fundação Roquette Pinto e, de novo, vinculada ao MEC. Implementada com a finalidade básica de desenvolver atividades teleducativas no País, de forma articulada, essa fundação coordena o Sistema Nacional de Radiodifusão Educativa (SINRED), institucionalizado em 1982, reunindo todas as emissoras de rádio e de televisão educativos. Além dos programas de ensino de $1^{2}$ e 2 - graus, de caráter supletivo ou não, a Fundação Roquette Pinto mantém uma programação diversificada: programas na TV e no rádio para idosos, programas para acompanhamento da vida universitária, como o "Universidade Aberta" e "Qualificação Profissional", integrando 235 programas de rádio e televisão com o respectivo material didático, a fim de qualificar professores leigos para o $1^{2}$ grau.

É oportuno lembrar que a instabilidade governamental tem incentivado o avanço do setor privado na teleducação. Destacam-se as investidas da Fundação Roberto Marinho e da Fundação Hoescht. No caso da primeira, há ênfase para o setor televisivo, ainda que se beneficie, também, dos cursos de suplência veiculados pelas rádios estatais, que adotam o material didático preparado pela Fundação Roberto Marinho para a televisão (Siqueira, Freitas, Haddad, 1987).

Existem ainda emissoras católicas e evangélicas que, em geral, destinam espaço de sua programação para emissões que, segundo Vigil (1986) e Fontecilla (1983), podem ser consideradas educativas. Um exemplo é a Rádio Pioneira de Teresina, emissora da Arquidiocese de Teresina, que 
veicula programas como o "Revista Sindical", produzido diariamente pelo Centro Piauiense de Ação Cultural; o "Chama Cultural", produzido pela Fundação Cultural Monsenhor Chaves e levado ao ar todos os sábados, e o "Boca da Noite", também aos sábados, em horário cedido à Pastoral da Juventude.

Ademais, considerando-se a educação, no conceito amplo antes citado (Freire, 1988), vê-se que dentre os cinco programas educativos de rádio mais difundidos em território nacional "C\&T"; "SBPC no Rádio"; "Noticioso de C\&T"; "UnB na Cultura" e "Uma Janela Para o Mundo", quatro são produzidos por universidades, como a Universidade de São Paulo e a Universidade de Brasília, e apenas um pertence à rede privada. Isto representa, em uma história com tantas siglas e tantas incertezas, a contribuição das instituições de ensino superior para os sistemas radioeducativos, ao mesmo tempo que justifica a pergunta: Rádio educativo — a serviço de quê e de quem?

\section{CONCEITO E FUNÇÕES}

Teleducação significa, basicamente, processo educativo que ocorre a distância, ou seja, a distinção entre a teleducação e os demais processos educativos é o meio utilizado. Como ressalta Horta (1973), o rádio deve ser visualizado por aqueles que o utilizam em educação como um meio dentre outros, que, integrado ou não aos demais, está a serviço do indivíduo, sujeito e objeto de todo processo educacional. Em linha similar de pensamento, Vigil (1986) conceitua rádio educativo como o meio que veicula conteúdos práticos para a vida das pessoas, possibilitando que estas conheçam o mundo, a fim de transformá-lo, na concepção de educação de Freire (1988).

Para Fontecilla (1983, p.9), a radiodifusão educativa se situa como "um meio de desenvolver a participação, a organização comunitária etc, dentro de uma nova perspectiva qual seja a de que o futuro da educação está profundamente unido ao futuro social de um povo". O autor inclui, neste conceito, qualquer ação que vise à formação, à capacitação, à 
evangelização e ao desenvolvimento dos indivíduos, o que permite incluir, no rol de programas educativos, tanto emissões de rádios católicas e evangélicas como as demais que visem, explicitamente, à formação do cidadão.

A partir do exposto, infere-se que as funções do rádio educativo são idênticas às do rádio em geral, com ênfase na função educativa, conforme detalhamento precedente. A UNESCO concebe esta função como suporte dos meios de comunicação, inclusive dos veículos comerciais, ainda que, na prática, se perceba que estes estão submetidos a critérios e interesses de natureza política e econômica, responsáveis, muitas vezes, por uma censura interna, velada ou declarada...

Nessa concepção, as emissoras de rádio educativo têm por finalidade básica promover emissões de conteúdo acentuadamente educativo, seja na linha formal ou não-formal. A teleducação formal se dá, de modo sistemático e propedêutico, valorizando a avaliação e objetivando a obtenção de títulos, diplomas ou certificados. A teleducação informal (mais recomendada pela ALER, por seu caráter descontraído e "leve", o que favorece a assimilação) tem conteúdos programáticos mais amplos, menor controle de objetivos e nenhuma exigência de títulos.

Assim, é incontestável que a teleducação, como força educativa, pode suprir lacunas não preenchidas pela escola, sobretudo nas nações e regiões menos favorecidas, onde as informações técnicas, as informações de aplicação imediata e as informações direcionadas a grupos profissionais, raciais, etários, religiosos são prementes. Porém, se seu poder concorre para reduzir o particularismo das comunidades, pode, também, agir em sentido contrário, massificando as culturas, fortalecendo os estereótipos e relegando a um plano inferior os valores genuínos. Esta assertiva justifica as vantagens e desvantagens da teleducação, relacionadas por Bordenave (1987) e por Siqueira, Freitas, Haddad (1989):

\section{a) Vantagens}

envolvimento de poucos educadores e comunicadores; possibilidade de alcance a um grande número de pessoas dispersas geograficamente, independente das características individuais; 
facilidade ao telealuno de estudar só ou em grupo, em casa ou em qualquer outro lugar;

adaptação ao ritmo de cada aluno, ou seja, respeito às diferenças individuais;

redução do custo de capacitação por telealuno - economia de transporte, alojamento e alimentação;

estímulo ao autodidatismo, mitigando a dependência do aluno ao professor;

complementação ao ensino formal.

b) desvantagens

alto índice de evasão, no caso da teleducação formal, diante da inexistência de um acompanhamento sistemático aos estudantes;

falta de hábito de autodidaxia, na realidade nacional;

massificação dos conteúdos, mesmo em se tratando de públicos heterogêneos;

dificuldade para desenvolver a participação ativa dos ouvintes na geração de conhecimento e de uma consciência crítica.

\section{RÁDIO EDUCATIVA DO PIAUÍ (REPI): IDENTIFICAÇÃO}

Confirmando a falta de organização da memória das instituições brasileiras e piauienses, em particular, apesar do esforço dos autores no sentido de reconstituírem a evolução histórica da REPI, mediante consulta a documentos e pessoas, os dados obtidos não favorecem uma avaliação profunda e consistente. Sabe-se que a Rádio Educativa do Piauí (REPI), emissora do governo do Estado, estreou no dia 2 de dezembro de 1988, com o nome de Rádio Antares, denominação que constitui uma homenagem à estrela representativa do Piauí na Bandeira Nacional.

A inauguração marcou a extinção do Centro de Teleducação (CETEL), criado em maio de 1986, pelo então governador Hugo Napoleão, e tendo como integrante único o Canal 2 de Televisão. Em substituição, o governador Alberto Silva criou a Fundação Antares, englobando a Rádio e a TV Antares. 
Ainda no primeiro ano de funcionamento, a emissora passou a operar com $10 \mathrm{kw}$ de potência (inicialmente, de $1 \mathrm{kw}$ ), durante 24 horas (a duração inicial era de 9 horas), atingindo um raio médio de $500 \mathrm{~km}$, abrangendo todo o Piauí e cidades fronteiriças do Maranhão e do Ceará, ainda que não se tenha informações precisas na identificação desses municípios. Atualmente, mesmo no ar por 24 horas, a emissora opera com lkw de potência, atingindo somente Teresina e cidades vizinhas.

Em 1991, com o início do governo Freitas Neto, a REPI mudou sua identidade. Foi extinta a Fundação Antares, "ressuscitado" o CETEL e restaurado o vínculo com a Fundação de Apoio ao Desenvolvimento da Educação no Piauí (FADEP). Quando do início desta pesquisa, a REPI mantinha uma grade de 25 programas locais, grade formalmente mantida, embora se saiba da criação de novos programas, sem a devida identificação do público-alvo. Verifica-se um aumento de programação informativa, com o radiojornalismo se expandindo de uma hora e quinze minutos para duas horas e trinta minutos, diárias.

Quanto à situação de recursos — ainda que de forma sucinta, pela precariedade de dados —, a REPI pode ser assim descrita:

Recursos humanos - a REPI faz parte do CETEL, que incorpora a Rádio e a TV Educativas, com um total de 159 funcionários, dos quais apenas 36 prestam serviço à Rádio. Tomando por base os dispositivos da legislação do radialista - Lei $\mathrm{n}^{2}$ 6.615, de 16 de dezembro de 1978, regulamentada pelos decretos $n^{9}$ s 84.134 , de 30 de outubro de 1979 , e 94.447, de 16 de dezembro de 1987, são considerados radialistas ou trabalhadores em emissoras de radiodifusão, como denomina o sindicato da categoria, independente das funções desempenhadas. Assim, paradoxalmente, indivíduos que desempenham atividades diversificadas, como camareiro, costureiro, cabeleireiro, carpintiero, cortineiro-estofador etc, constantes do Quadro Anexo ao Decreto ${ }^{\mathrm{e}}{ }^{84.134}$, são considerados como radialistas. (Movimento Nacional dos Radialistas, 1991).

Recursos financeiros - por sua própria vinculação, a REPI é mantida financeiramente pelo governo do Estado, o que tornou inviável a 
identificação exata dos recursos destinados à REPI pela FADEP, visto que não se constitui em unidade orçamentária.

Recursos materiais - Quanto à sua estrutura física, a REPI possui prédio próprio - situado na Avenida Valter Alencar, $\mathrm{n}^{\mathrm{e}}$ 2021, Bairro Monte Castelo, CEP 64.065, Teresina-PI, Fone: (086) 223-8595. Dispõe dos seguintes equipamentos: torre de transmissão, com um transmissor de $1 \mathrm{KW}$; "Lynk", emissor de sinal sonoro; equalizador, que garante a qualidade do som; compressor de áudio, que fixa o áudio em determinado volume, e estúdios de "ar" e de gravação, com mesas de áudio, de 8 e 4 canais, respectivamente.

\section{Formas de falseamento da informação no rádio}

A manipulação da informação como "consciente intervenção técnica" (Enzensberger, 1978, p.67), na prática jornalística, passou a ser efetivada com maior intensidade a partir da inversão da base original da imprensa (Habermas, 1985), no início do século XIX, em face do estabelecimento do Estado de Direito Burguês, com a legalização da difusão pública da informação, tendo em vista o avanço das técnicas de produção econômica do sistema capitalista. Esta inversão corresponde à transformação de instituições privadas em públicas, ou seja, a esfera privada da imprensa torna-se pública, devido à instituição legal do mecanismo das "concessões" pelo Estado.

Todos esses aspectos foram objeto de estudo da Teoria Crítica iniciada com a Escola de Frankfurt, que envolvia a análise da problemática dos anos 30: a crise da democracia liberal burguesa, a ascensão do fascismo, a regressão do movimento socialista na Europa e o avanço da sociedade de consumo nos Estados Unidos. Para Lopes (1990, p.49), na perspectiva frankfurtiana, a sociedade e a cultura são o resultado da associação entre o capital e o progresso técnico, sendo que o capital passa a produzir uma satisfação "guiada" das necessidades materiais, transformando o homem em objeto de administração. Foram os frankfurtianos, mais precisamente 
Walter Benjamin, que desenvolveram o conceito de "Indústria Cultural", fundamentado no binômio cultura erudita-cultura de massa, retratando as mudanças ocorridas na organização da cultura na sociedade moderna.

Apesar das críticas à Teoria Crítica (Baudrillard, 1985, Silva, 1985), estudos recentes, baseados nessa teoria, apontam formas de manipulação da informação, caracterizando-a como "produção de segunda natureza", ou seja, artificializada. Nessa perspectiva, a notícia, por exemplo, é considerada mera mercadoria, além de veículo ideológico e agente político (Marcondes Filho, 1989). Em 1983, a Comissão Internacional para o Estudo dos Problemas da Comunicação aponta várias "lacunas e deformações" existentes no sistema de comunicação das sociedades contemporâneas. Dentre elaš-, destaca a deformação do conteúdo, por meio de espetacularização, da fragmentação, do conteúdo negativo, das inexatidões e falsificações e da interpretação parcial. Marcondes Filho denomina tal processo de "falseamento ou encobrimento" da informação, categorizando-o, na imprensa escrita e falada, em três formas: a visão fragmentada e personalizada dos processos sociais; o uso da técnica e da lingüística; a política do destaque e da supressão de informações.

Quando do processo de alienação do trabalho, em que ocorre uma ruptura entre o homem e o produto de sua atividade, percebe-se que a fragmentação é a forma de disposição do mundo na perspectiva burguesa, responsável por mentalidades que percebem o contexto social sem nenhum fio ordenador. A fragmentação noticiosa é uma "decorrência natural", em que a notícia aparece dissociada do seu contexto, como um dado solto, com ênfase para aspectos como o sensacional e a aparência, em detrimento de outros. Logo, a redução da História em fragmentos desconexos é uma técnica manipuladora utilizada por radialistas, jornalistas, historiadores, sociólogos etc, que impede a sociedade de assimilar o conjunto dos processos sociais e de discernir quem detém as rédeas desses processos e para que direção a conduzem.

A personalização dos fatos sociais e jornalísticos está no núcleo da explicação histórica burguesa, em que a História surge como responsabilidade não das classes sociais, mas de indivíduos, que ora 
aparecem como super-heróis, ora como bodes expiatórios, dependendo dos interesses políticos e econômicos dominantes.

Os meios de comunicação de massa (MCM) ao utilizarem formas lingüísticas em que predominam o tom oficial e as formulações anônimas do tipo "fontes bem informadas", "porta-voz oficial", tentam transmitir, independente do grau de veracidade, mensagens neutras e "acima de qualquer suspeita". Também o uso de termos técnicos, gráficos, tabelas e de outros recursos que dificultem a compreensão dos conteúdos (um bom exemplo foi o lançamento do "Plano Collor" pelo governo federal) são elementos representativos do processo de manipulação.

Ainda segundo Marcondes Filho (1989), se as formas anteriores de distorção estão ou podem estar presentes no discurso geral dominante da sociedade, a política do destaque e da supressão da informação é peculiar a radialistas e jornalistas, através do ato consciente de deturpar os fatos históricos e sociais. Diante de interesses empresariais, os MCMs extraem da realidade o que lhes convém, redimensionando-a sob um prisma artificial e ludibriador.

Em síntese, entre a ocorrência de um fato e a sua apresentação ao público via MCM, existem várias modalidades de intervenções técnicas que alteram tanto o caráter como o efeito da informação. No entanto, se para Enzensberger (1978) toda e qualquer utilização dos meios pressupõe uma manipulação - e a questão não é se os MCMs são manipulados ou não, mas quem a faz —, para Marcondes Filho (1989), nem todas as formas de falseamento se dão, necessariamente, de forma intencional. Fazem parte das formas jornalísticas de interpretar e forjar o real, através da adaptação ideológica, da estruturação da informação com fins de valorização e de interesse de classes, ou seja, integram a lógica de mercado que rege a produção simbólica nas sociedades capitalistas contemporâneas.

No caso específico do rádio, este, como veículo que conquistou grandes índices de aceitação popular no mundo inteiro, tornou-se alvo de manipulação política e ideológica desde o sucesso obtido por Goebbels, na propaganda do nazismo e, em termos de Brasil, como mencionado, 
desde a Revolução de 1930. O falseamento da informação no rádio é facilitado, visto seu amplo poder de penetração, sobretudo entre a população de baixa renda, desprovida de mecanismos críticos para julgar e refutar as mensagens manipuladas e manipulatórias. As próprias características do rádio como veículo essencialmente sonoro, que utiliza recursos da linguagem coloquial, elemento marcante da cultura dos setores rurais e das periferias urbanas, facilitam o ato de "falsear" ou "encobrir" as informações, obtendo aceitação e assimilação por parte da maioria dos ouvintes.

Por outro lado, as formas jornalísticas de interpretar e forjar o real não são exclusivas de veículos privados ou estatais, mas estes últimos são mais propícios, pois, geralmente, funcionam como "porta-vozes" oficiais do governo, o que determina a presença constante de formas de pensamento censurado, dissimuladamente ou não, sobretudo a personalização, utilizada para proporcionar efeito positivo aos atos do governo e levar à execração pública seus opositores. Assim, as emissoras estatais, ditas "educativas" ou não, utilizam ou tendem a utilizar todo esse potencial "comunicativo" do veículo rádio. Como decorrência, no caso da REPI, o risco de presença de formas de pensamento censurado é, aparentemente, maior, o que pode influir, de forma decisiva, em sua audiência, tanto no aspecto quantitativo, como no que tange à delimitação do perfil de seu público.

\section{Metodologia}

POPULAÇÃO E AMOSTRA

O município de Teresina-PI, com $1.809 \mathrm{~km}^{2}$, possui uma população estimada em 596.191 habitantes, distribuídos, geograficamente, nas zonas urbana e rural, sendo que, aproximadamente, $95 \%$ se concentram no perímetro urbano (Fundação IBGE, 1991).

A partir da concepção generalizada de que pesquisas deste porte demandam amostras, e em face da natureza do estudo, optou-se pela 
amostra não probabilística por fácil acesso ou amostragem de conveniência (Berquo, 1980), em que o critério para a seleção das unidades amostrais é a facilidade de acesso a esses elementos. A amostragem foi composta de 150 pessoas residentes em Teresina e representativas, eqüitativamente, dos setores do perímetro urbano - bairros adjacentes, centro e periferia.

Dentre os entrevistados, 53,33\% eram do sexo masculino e 46,67\%, do sexo feminino. A idade variou entre 10 e 64 anos, prevalecendo a faixa etária de 20 a 29 anos em 38,67\% dos informantes, seguida da faixa de 15 a 19 anos, em $26 \%$, registrando-se coincidência de $11,33 \%$ para as idades abaixo de 15 anos e, para o intervalo de 30 a 39 anos, 9,34\% dos pesquisados tinham entre 40 e 49 anos e 3,33\% mais de 50 anos.

A caracterização da amostra em todos os seus itens está representada nas tabelas de 1 a 8 a seguir.

\section{Tabela 1 - Idade}

\begin{tabular}{|c|c|c|c|c|c|c|c|c|}
\hline \multirow{2}{*}{$\begin{array}{l}\text { Idade } \\
\text { (anos) }\end{array}$} & \multicolumn{2}{|c|}{$\begin{array}{c}\text { Bairros } \\
\text { Adjacentes }\end{array}$} & \multicolumn{2}{|c|}{ Centro } & \multicolumn{2}{|c|}{ Periferia } & \multicolumn{2}{|c|}{ Total } \\
\hline & $\mathrm{N}$ & $\%$ & $\mathrm{~N}$ & $\%$ & $\mathrm{~N}$ & $\%$ & $\mathrm{~N}$ & $\%$ \\
\hline Abaixo del5 & 1 & 6,67 & 0 & 0,0 & 6 & 18,18 & 7 & 11,48 \\
\hline De 15 a 19 & 3 & 20,00 & 3 & 23,08 & 11 & 33,33 & 17 & 27,87 \\
\hline De 20 a 29 & 8 & 53,33 & 8 & 61,54 & 9 & 27,27 & 25 & 40,98 \\
\hline De 30 a 39 & 2 & 13,33 & 2 & 15,38 & 3 & 9,09 & 7 & 11,48 \\
\hline De 40 a 49 & 1 & 6,67 & 0 & 0,00 & 3 & 9,09 & 4 & 6,56 \\
\hline Mais de 50 & 0 & 0,00 & 0 & 0,00 & 1 & 3,03 & 1 & 1,64 \\
\hline Totais & 15 & 100,00 & 13 & 100,00 & 33 & 100,00 & 61 & 100,00 \\
\hline
\end{tabular}


Tabela $2-$ Sexo

\begin{tabular}{|c|c|c|c|c|c|c|c|c|}
\hline \multirow[t]{2}{*}{ Sexo } & \multicolumn{2}{|c|}{$\begin{array}{c}\text { Bairros } \\
\text { Adjacentes }\end{array}$} & \multicolumn{2}{|c|}{ Centro } & \multicolumn{2}{|c|}{ Periferia } & \multicolumn{2}{|c|}{ Total } \\
\hline & $\mathrm{N}$ & $\%$ & $\mathrm{~N}$ & $\%$ & $\mathrm{~N}$ & $\%$ & $\mathrm{~N}$ & $\%$ \\
\hline Masculino & 9 & 60,00 & 8 & 61,54 & 13 & 39,39 & 30 & 49,18 \\
\hline Feminino & 6 & 40,00 & 5 & 38,46 & 20 & 60,61 & 31 & 50,82 \\
\hline Totais & 15 & 100,00 & 13 & 100,00 & 33 & 100,00 & 61 & 100,00 \\
\hline
\end{tabular}

Tabela 3 - Nível de Escolaridade

\begin{tabular}{|c|c|c|c|c|c|c|c|c|}
\hline \multirow[t]{2}{*}{ Escolaridade } & \multicolumn{2}{|c|}{$\begin{array}{c}\text { Bairros } \\
\text { Adjacentes }\end{array}$} & \multicolumn{2}{|c|}{ Centro } & \multicolumn{2}{|c|}{ Periferia } & \multicolumn{2}{|c|}{ Total } \\
\hline & $\mathrm{N}$ & $\%$ & $\mathrm{~N}$ & $\%$ & $\mathrm{~N}$ & $\%$ & $\mathrm{~N}$ & $\%$ \\
\hline $1^{2}$ Grau Incomp. & 7 & 46,67 & 0 & 0,00 & 17 & 51,52 & 24 & 39,34 \\
\hline $\mathrm{I}^{\mathrm{a}}$ Grau Comp. & 1 & 6,67 & 0 & 0,00 & 3 & 9,09 & 4 & 6,56 \\
\hline $2^{\mathrm{a}}$ Grau Incomp. & 2 & 13,33 & 1 & 7,69 & 1 & 3,03 & 4 & 6,56 \\
\hline $2^{\mathrm{a}}$ Grau Comp. & 1 & 6,67 & 5 & 38,46 & 5 & 15,15 & 11 & 18,03 \\
\hline $\begin{array}{l}3^{\mathrm{a}} \text { Grau Incomp. } \\
3^{\mathrm{a}} \text { Grau Comp./ }\end{array}$ & 3 & 20,00 & 3 & 23,08 & 5 & 15,15 & 11 & 18,03 \\
\hline Pós-Graduação & 1 & 6,67 & 4 & 30,77 & 2 & 6,06 & 7 & 11,48 \\
\hline Totais & 15 & 100,00 & 13 & 100,00 & 33 & 100,00 & 61 & 100,00 \\
\hline
\end{tabular}


Tabela 4 - Renda Mensal Familiar

\begin{tabular}{|c|c|c|c|c|c|c|c|c|}
\hline \multirow[t]{2}{*}{$\begin{array}{l}\text { Renda Familiar } \\
\text { (Salário Minimo) }\end{array}$} & \multicolumn{2}{|c|}{$\begin{array}{c}\text { Bairros } \\
\text { Adjacentes }\end{array}$} & \multicolumn{2}{|c|}{ Centro } & \multicolumn{2}{|c|}{ Periferia } & \multicolumn{2}{|c|}{ Total } \\
\hline & $\mathrm{N}$ & $\%$ & $\mathrm{~N}$ & $\%$ & $\mathrm{~N}$ & $\%$ & $\mathrm{~N}$ & $\%$ \\
\hline Até 1 & 4 & 26,67 & 1 & 7,69 & 19 & 57,58 & 24 & 39,34 \\
\hline De 2 a 5 & 9 & 60,00 & 8 & 61,54 & 4 & 12,12 & 21 & 34,43 \\
\hline De 6 a 20 & 1 & 6,67 & 3 & 23,08 & 3 & 9,09 & 7 & 11,48 \\
\hline Renda Omitida & 1 & 6,67 & 1 & 7,69 & 7 & 21,21 & 9 & 14,75 \\
\hline Totais & 15 & 100,00 & 13 & 100,00 & 33 & 100,00 & 61 & 100,00 \\
\hline
\end{tabular}

Tabela 5 - Estado Civil

\begin{tabular}{|c|c|c|c|c|c|c|c|c|}
\hline \multirow[t]{2}{*}{ Estado Civil } & \multicolumn{2}{|c|}{$\begin{array}{c}\text { Bairros } \\
\text { Adjacentes }\end{array}$} & \multicolumn{2}{|c|}{ Centro } & \multicolumn{2}{|c|}{ Periferia } & \multicolumn{2}{|c|}{ Total } \\
\hline & $\mathrm{N}$ & $\%$ & $\mathrm{~N}$ & $\%$ & $\mathrm{~N}$ & $\%$ & $\mathrm{~N}$ & $\%$ \\
\hline Solteiro & 10 & 66,67 & 13 & 100,00 & 23 & 69,70 & 46 & 75,41 \\
\hline Casado & 4 & 26,67 & 0 & 0,00 & 9 & 27,27 & 13 & 21,31 \\
\hline Separado & 0 & 0,00 & 0 & 0,00 & 0 & 0,00 & 0 & 0,00 \\
\hline Viúvo & 1 & 6,67 & 0 & 0,00 & 0 & 0,00 & 1 & 1,64 \\
\hline Amasiado & 0 & 0,00 & 0 & 0,00 & 1 & 3,03 & 1 & 1,64 \\
\hline Totais & 15 & 100,00 & 13 & 100,00 & 33 & 100,00 & 61 & 100,00 \\
\hline
\end{tabular}


Tabela 6 - Profissão

\begin{tabular}{|c|c|c|c|c|c|c|c|c|}
\hline \multirow[t]{2}{*}{ Profissão } & \multicolumn{2}{|c|}{$\begin{array}{c}\text { Bairros } \\
\text { Adjacentes }\end{array}$} & \multicolumn{2}{|c|}{ Centro } & \multicolumn{2}{|c|}{ Periferia } & \multicolumn{2}{|c|}{ Total } \\
\hline & $\mathrm{N}$ & $\%$ & $\mathrm{~N}$ & $\%$ & $\mathrm{~N}$ & $\%$ & $\mathrm{~N}$ & $\%$ \\
\hline Estudante & 4 & 26,67 & 1 & 7,69 & 16 & 48,48 & 21 & 34,43 \\
\hline Func. Público & 1 & 6,67 & 3 & 23,08 & 4 & 12,12 & 8 & 13,11 \\
\hline $\begin{array}{l}\text { Professor } \\
\text { Jornalista/ }\end{array}$ & 0 & 0,00 & 2 & 15,38 & 3 & 9,09 & 5 & 8,20 \\
\hline Radialista & 3 & 20,00 & 3 & 23,08 & 3 & 9,09 & 9 & 14,75 \\
\hline Comerciário & 1 & 6,67 & 1 & 7,69 & 1 & 3,03 & 3 & 4,92 \\
\hline Doméstica & 1 & 6,67 & 0 & 0,00 & 3 & 9,09 & 4 & 6,56 \\
\hline $\begin{array}{l}\text { Comerciante } \\
\text { Outras }\end{array}$ & 0 & 0,00 & 0 & 0,00 & 3 & 9,09 & 3 & 4,92 \\
\hline Profissões (") & 5 & 33,33 & 3 & 23,08 & 0 & 0,00 & 8 & 13,11 \\
\hline Totais & 15 & 100,00 & 13 & 100,00 & 33 & 100,00 & 61 & 100,00 \\
\hline
\end{tabular}

* Profissões com 1 ou 2 pontos cada uma.

Tabela 7 - Religião

\begin{tabular}{l|rr|rr|rr|rr}
\hline \multicolumn{1}{c|}{ Religião } & \multicolumn{2}{|c|}{$\begin{array}{c}\text { Bairros } \\
\text { Adjacentes }\end{array}$} & \multicolumn{2}{|c|}{ Centro } & \multicolumn{2}{c|}{$\begin{array}{c}\text { Periferia } \\
\bullet\end{array}$} \\
\hline & $\mathrm{N}$ & $\%$ & $\mathrm{~N}$ & $\%$ & $\mathrm{~N}$ & $\%$ & $\mathrm{~N}$ & $\%$ \\
& & & & & & & & \multicolumn{2}{c}{ Total } \\
Catolicismo & 13 & 86,67 & 7 & 53,85 & 29 & 87,88 & 49 & 80,33 \\
Judaismo & 1 & 6,67 & 0 & 0,00 & 0 & 0,00 & 1 & 1,64 \\
Protestantismo & 0 & 0,00 & 2 & 15,38 & 1 & 3,03 & 3 & 4,92 \\
Espiritismo & 0 & 0,00 & 1 & 7,69 & 0 & 0,00 & 1 & 1,64 \\
Nenhuma & 0 & 0,00 & 2 & 15,38 & 3 & 9,09 & 5 & 8,20 \\
Sem Resposta & 1 & 6,67 & 1 & 7,69 & 0 & 0,00 & 2 & 3,28 \\
& & & & & & & & \\
Totais & 15 & 100,00 & 13 & 100,00 & 33 & 100,00 & 61 & 100,00
\end{tabular}




\section{Tabela 8 - Afinidade Política}

\begin{tabular}{|c|c|c|c|c|c|c|c|c|}
\hline \multirow{2}{*}{$\begin{array}{l}\text { Idade } \\
\text { (anos) }\end{array}$} & \multicolumn{2}{|c|}{$\begin{array}{c}\text { Bairros } \\
\text { Adj acentes }\end{array}$} & \multicolumn{2}{|c|}{ Centro } & \multicolumn{2}{|c|}{ Periferia } & \multicolumn{2}{|c|}{ Total } \\
\hline & $\mathrm{N}$ & $\%$ & $\mathrm{~N}$ & $\%$ & $\mathrm{~N}$ & $\%$ & $\mathrm{~N}$ & $\%$ \\
\hline PT & 1 & 6,67 & 1 & 7,69 & 4 & 12,12 & 6 & 9,84 \\
\hline PMDB & 0 & 0,00 & 1 & 7,69 & 0 & 0,00 & 1 & 1,64 \\
\hline PFL & 1 & 6,67 & 0 & 0,00 & 5 & 15,15 & 6 & 9,84 \\
\hline PSDB & 1 & 6,67 & 0 & 0,00 & 0 & 0,00 & 1 & 1,64 \\
\hline PCB & 1 & 6,67 & 1 & 7,69 & 0 & 0,00 & 2 & 3,28 \\
\hline PH & 1 & 6,67 & 1 & 7,69 & 0 & 0,00 & 2 & 3,28 \\
\hline Nenhuma & 2 & 13,33 & 0 & 0,00 & 10 & 30,30 & 12 & 19,67 \\
\hline Sem Resposta & 8 & 53,33 & 9 & 69,23 & 14 & 42,42 & 31 & 50,82 \\
\hline Totais & 15 & 100,00 & 13 & 100,00 & 33 & 100,00 & 61 & 0,00 \\
\hline
\end{tabular}

MATERIAL E PROCEDIMENTOS

Quando da coleta de dados, utilizou-se a técnica de entrevista semiestruturada, com a incorporação de questões dos tipos aberta, fechada e mista (Anexo). A parte inicial do roteiro se referia à identificação do entrevistado. A segunda parte, com 10 itens, envolvia a freqüência e os motivos da audiência; os programas preferidos e as causas da preferência; opinião sobre a programação da REPI; circunstâncias de audição; existência e formas de participação na programação; tempo médio de audiência por dia; grau de credibilidade nas notícias veiculadas e conhecimento do caráter estatal da emissora. 
Sob a responsabilidade dos autores, a efetivação da entrevista, inclusive o pré-teste, ocorreu a domicílio, de 19 de agosto a 30 de setembro de 1991. A codificação e a tabulação das respostas foram manuais, recorrendose à técnica do percentual. O universo foi considerado sob dois pontos de vista: global (todos os entrevistados) e estratificado (bairros adjacentes, centro e periferia).

Utilizou-se, ainda, a técnica de observação sistemática (Marconi, Lakatos, 1990), para acompanhamento da programação. Durante uma semana (de 15 a 21 de dezembro de 1992), em horários escalonados, dentre as 24 horas diárias de funcionamento da rádio, procedeu-se à gravação de seus programas, para compreender melhor as colocações dos entrevistados e avaliar, com mais segurança, o conteúdo informativo/ educativo das mensagens. Com o mesmo fim, coletou-se, na linha da pesquisa documental, uma amostra de três scripts dos principais programas.

\section{Audiência e perla do público}

\section{AUDIÊNCIA}

Como demonstra a Tabela 9, dos entrevistados 59,33\% não ouvem a rádio, sobretudo os residentes nos bairros adjacentes e no centro. Em contraposição, 40,67\% são ouvintes, a maioria dos quais $(54,10 \%)$ moradores da periferia, o que confirma a abordagem da Comissão Internacional para o Estudo dos Problemas da Comunicação (1983, p.122): o rádio educativo ou não é o "primeiro meio de distração de massas em plano mundial", apesar do caráter atraente da TV, que, no entanto, continua inacessível a muitas famílias brasileiras. 


\section{Tabela 9 - Audiência da REPI}

\begin{tabular}{l|r|r|r|r|r|r|r|r}
\hline $\begin{array}{c}\text { Ouve a } \\
\text { REPI }\end{array}$ & \multicolumn{2}{|c|}{ B. Adjacentes } & \multicolumn{2}{|c|}{ Centro } & \multicolumn{2}{c|}{ Periferia } & \multicolumn{2}{c}{ Total } \\
& N & $\%$ & N & $\%$ & N & $\%$ & N & $\%$ \\
Sim & 15 & 30 & 13 & 26 & 33 & 66 & 61 & 40,67 \\
Não & 35 & 70 & 37 & 74 & 17 & 34 & 89 & 59,33 \\
Totais & 50 & 100 & 50 & 100 & 50 & 100 & 150 & 100,00 \\
\hline
\end{tabular}

* Bairros Adjacentes

Dentre as justificativas citadas para a não audiência, a de maior peso, nos três setores - bairros adjacentes, centro e periferia -, foi a preferência por FMs, com o total de $25,84 \%$. Isto reforça, em face da marca definidamente musical das FMs, a função de entretenimento do rádio, em prejuízo das funções educativa e informativa. Treze pessoas $(14,61 \%)$ de profissões variadas, oito das quais do centro, alegaram não ter tempo, reafirmando o estigma da falta de tempo que vem se incorporando à concepção de uma falsa modernidade, sobretudo nas classes mais favorecidas, o que se reforça com o fato de ninguém na periferia ter usado esse pretexto. No entanto, o mais surpreendente é que 12 pesquisados (11 morando nos bairros adjacentes e centro) afirmaram não ter o hábito de ouvir rádio e o mesmo número desconhece a REPI, o que representa indícios de uma carência de "marketing" da emissora, e também, da superação do rádio por outros veículos de comunicação, principalmente dentre os grupos com maior instrução formal e poder aquisitivo. Somente dois indivíduos manifestaram, explicitamente, desinteresse pela programação da REPI, mas $24,72 \%$ se omitiram quanto às causas da não audiência, o que dificulta a avaliação do grau de receptividade da rádio na realidade teresinense. 
Apesar do alto índice de abstenção nos três segmentos (34,43\%), a programação, considerada, ora "interessante", ora "alternativa", ora "variada", ora "regional", foi sempre o item mais citado como motivo de audiência, coincidentemente, por $34,43 \%$ dos ouvintes. Ainda sob a denominação de Rádio Antares, havia uma programação alternativa, isto é, fora dos padrões convencionais das demais emissoras de Teresina, o que legitima a colocação de um dos depoentes: "A REPI não segue a linha comercial". Mas a tendência atual é seguir os modelos locais existentes, salvo quanto à intensidade dos serviços de utilidade pública e à ausência de comerciais. Um exemplo significativo é a recente "transposição" para a REPI de programas considerados "campeões de audiência", com todas as características-formais e de conteúdo, independente de seu objetivo maior - a educação. Tal descomprometimento se agraVa quando a coleta de dados mostra que dos 150 sujeitos, somente para três deles, todos de bairros adjacentes, o conteúdo educativo da programação é o responsável pela audiência da REPI. Retomando Vigil (1986),.para quem educar é dialogar e para quem a base da educaçãoradiofônica está na possibilidade de comunicação do povo com o povo através do rádio, se $98 \%$ dos pesquisados não reconhecem a função educativa do rádio, urge esta repensar seus objetivos, mediante o delineamento do público que pretenda atingir, revendo-se a questão: REPI, a serviço de quê e de quem?

A outra justificativa mais citada, dentre os ouvintes, nos bairros adjacentes, centro e periferia foi os noticiários da REPI (14,75\%), que reforça a função informativa (Fontecilla, 1983 e Ortriwano, 1989, p.89). Este último afirma: "o objetivo da informação como mensagem radiofônica é manter o ouvinte a par de tudo o que de interesse e atualidade ocorre no mundo". Aos programas musicais $(8,20 \%)$ e à qualidade sonora $(4,92 \%)$ seguiram-se itens dispersos, como o fornecimento da hora e locutores específicos, com uma única menção.

\section{AUDIÊNCIA E FREQÜÊNCIA}

A audiência dá-se conforme a freqüência descrita na Tabela 10, e a freqüência diária prepondera nos bairros adjacentes (60\%) e na periferia 
(54,55 \%), em contraste com o predomínio da audição ocasional (53,85\%), para os residentes no centro. Isso constata, mais uma vez, a força do rádio em comunidades mais carentes, referendada por Horta (1989), visto que a comunicação radiofônica independe da escolaridade do público, graças à sua oralidade, como traço marcante.

Tabela 10 - Freqüência da Audiência da REPI

\begin{tabular}{|c|c|c|c|c|c|c|c|c|}
\hline \multirow[t]{2}{*}{ Freqüência } & \multicolumn{2}{|c|}{ B. A.* } & \multicolumn{2}{|c|}{ Centro } & \multicolumn{2}{|c|}{ Periferia } & \multicolumn{2}{|c|}{ Total } \\
\hline & № & $\%$ & № & $\%$ & № & $\%$ & № & $\%$ \\
\hline Diária & 9 & 60,00 & 5 & 38,46 & 18 & 54,55 & 32 & 52,46 \\
\hline Semanal & 2 & 13,33 & - & - & 3 & 9,09 & 5 & 8,19 \\
\hline Quinzenal & - & - & - & - & - & - & - & - \\
\hline Mensal & 1 & 6,67 & - & - & 1 & 3,03 & 2 & 3,28 \\
\hline Rara & 2 & 13,33 & 7 & 53,85 & 10 & 30,30 & 19 & 31,15 \\
\hline Sem Especif. & 1 & 6,67 & 1 & 7,69 & 1 & 3,03 & 3 & 4,92 \\
\hline Totais & 15 & 100,00 & 13 & 100,00 & 33 & 100,00 & 61 & 100,00 \\
\hline
\end{tabular}

* Bairros Adjacentes

Neste momento, é mister acentuar que a questão sobre o tempo médio diário destinado à audição de rádio em geral registrou os índices mais altos para: duas horas, com $24,59 \%$; uma hora, com $13,11 \%$ e $9,84 \%$, tanto para seis como para quatro horas, sempre com maior representatividade dos ouvintes da periferia, e, em seguida, dos bairros adjacentes. Logo após, se pretendeu conhecer por quantos minutos, dentro deste tempo médio, os pesquisados ouviam a REPI. Os resultados coletados mostraram que o significativo percentual de 39,34\% de ouvintes dedicavam de uma a duas horas diárias à REPI, sem grandes diferenças 
estatísticas para as três localidades estudadas. Estes dados são alentadores, pois, a exemplo do prescrito por Porchat (1989), a REPI parece ter um público cativo, restando a seus administradores delineá-lo com mais precisão e direcionar suas ações para esse público, enfatizando seu caráter educativo. Assim, podem ampliar o público fiel, resgatando, inclusive, os numerosos ouvintes eventuais - 39,35\% - distribuídos nas freqüências mensal, rara e indefinida, descritas antes, na Tabela 2.

Quanto às circunstâncias de audição, independente do local de residência, dentre os ouvintes da REPI, predomina o hábito de ouvir rádio simultaneamente à realização de atividades cotidianas $(67,21 \%)$, com ênfase para os serviços domésticos, nos três segmentos. O rádio, sem dúvida, é o MCM que mais se integra à dinamicidade da sociedade contemporânea, desde que, como salienta Porchat (1989), "rádio é só audição". Nisto está sua maior vantagem e a justificativa mais incisiva para sua utilização como meio de educação informal, mas, paradoxalmente, sua maior desvantagem, no sentido da teleducação formal, quando se exigiria do ouvinte atenção integral, ainda que se saiba da falta de. autodidaxia no Brasil (Bordenave,. 1987)

Por isto, a linguagem no rádio educativo deve redobrar os cuidados em relação à sua forma de apresentação, obedecendo aos critérios de clareza, repetição, simplicidade, nitidez e motivação de que falam Fontecilla (1983), Porchat (1989) e Prado (1989).

PERFIL DO PÚBLICO

Quanto ao perfil do público-ouvinte da REPI, minuciosamente nas tabelas de 1 a 8 , os resultados indicam o predomínio, na periferia, da faixa etária de 15 a 19 anos, nos bairros adjacentes e centro, de 20 a 29 anos, culminando com o percentual total de $40,98 \%$, prevalecendo, no cômputo geral, o sexo feminino, com $50,82 \%$.

O nível de escolaridade de maior concentração é o de $1^{\mathrm{e}}$ grau incompleto $(39,34 \%)$, ainda que no centro o 2- grau completo tenha prevalecido. É 
provável que o nível de escolaridade se reflita na renda mensal familiar, pois, $57,58 \%$ dos ouvintes da periferia recebem até um salário mínimo, e nos bairros adjacentes e centro a renda mais citada é de dois a cinco salários, o que implica uma provável melhoria de vida. Em todos os segmentos estudados, os ouvintes são predominantemente solteiros $(75,41 \%)$, católicos $(80,33 \%)$ e sem afinidade política declarada $(70,49 \%)$, distribuídos entre estudantes $(34,43 \%)$, jornalistas/radialistas $(14,75 \%)$, funcionários públicos $(13,11 \%)$, professores $(8,20 \%)$ e domésticas $(6,56 \%)$, além de outras profissões, como camelô, economista, geógrafo, pintor, com um ou dois pontos, cada uma.

Todos esses resultados reforçam as conclusões dos estudiosos da área, que reiteram o prestígio do rádio numa fase em que o acesso ao consumo cultural, antes restrito a pequenas parcelas da população, hoje, para Lopes (1990), incorpora-se, com rapidez, às classes de baixa renda, privilegiando o rádio, não só por sua oralidade, mas pelo seu preço menos elevado e pela facilidade de uso a qualquer hora e lugar.

Programação

PROGRAMAS DE MAIOR AUDIÊNCIA

A Tabela 11 mostra a grade dos sete programas mais citados, pois os votos restantes estão dispersos, sem consenso. Dentre eles, estão dois eminentemente urbanos ("Rádio Movimento" e "Comando 800"), com ênfase para a programação musical e o gênero variedades, e dois, fundamentalmente rurais ("Brasil Caboclo" e "Vozes do Amanhecer"), seguindo a mesma linha dos anteriores, embora com informações direcionadas para o homem do campo e da periferia. 
Tabela 11 - Programas de Maior Audiência da REPI

\begin{tabular}{|c|c|c|c|c|c|c|c|c|}
\hline \multirow{2}{*}{$\begin{array}{c}\text { Ordem de } \\
\text { Classif./Prog. }\end{array}$} & \multicolumn{2}{|c|}{ B. A.* } & \multicolumn{2}{|c|}{ Centro } & \multicolumn{2}{|c|}{ Periferia } & \multicolumn{2}{|c|}{ Total } \\
\hline & № & $\%$ & № & $\%$ & № & $\%$ & $\mathrm{~N}^{2}$ & $\%$ \\
\hline 1² Rádio & & & & & & & & \\
\hline $\begin{array}{l}\text { Movimento } \\
2^{\underline{2}} \text { Brasil }\end{array}$ & 3 & 18,75 & 6 & 26,09 & 5 & 19,23 & 14 & 21,54 \\
\hline Caboclo & 1 & 6,25 & 0 & - & 11 & 42,31 & 12 & 18,46 \\
\hline $3^{2}$ Comando 800 & 4 & 25,0 & 5 & 21,74 & 3 & 11,54 & 12 & 18,46 \\
\hline $\begin{array}{l}4^{\circ} \text { Jornal } 800 \\
5^{\circ} \text { Vozes do }\end{array}$ & 1 & 6,25 & 7 & 30,43 & 3 & 11,54 & 11 & 16,92 \\
\hline $\begin{array}{l}\text { Amanhecer } \\
6^{\circ} \text { Circuito }\end{array}$ & 2 & 12,50 & 3 & 13,04 & 4 & 15,38 & 9 & 13,85 \\
\hline $\begin{array}{l}\text { Noturno } \\
7^{9} \text { Cadernos }\end{array}$ & 4 & 25,00 & 0 & - & 0 & - & 4 & 6,15 \\
\hline de Cidade & 1 & 6,25 & 2 & 8,70 & 0 & - & 3 & 4,62 \\
\hline Totais & 16 & 100,00 & 23 & 100,00 & 26 & 100,00 & 65 & 100,00 \\
\hline
\end{tabular}

* Bairros Adjacentes

OBS: Cada pesquisado podia indicar mais de uma opção

Confirmando esta seleção, $31,39 \%$ das respostas' apontam a programação musical como fator decisivo para sua opção, superada, apenas, no centro, onde o conteúdo informativo ocupa o primeiro lugar $(46,15 \%)$, o qual, no total, vem logo após a programação musical, com $23,25 \%$. As outras dimensões mais citadas, nos três setores, são: horário, $19,77 \%$; locutor, $18,60 \%$, e a duração do programa, $1,16 \%$.

Somente $22,95 \%$ dos ouvintes (mais na periferia e menos no centro), 
participam ativamente na programação da REPI, recorrendo, preferencialmente, ao telefone - mais para pedidos musicais, com o índice elevado de $85,71 \%$ - e ao contato pessoal com o índice de $14,29 \%$. A participação via carta ou outro documento escrito não ocorre, circunstanciando o domínio da oralidade em relação à escrita, o que merece reflexão.

PROGRAMAÇÃO, FUNÇÕES E FORMAS DE FALSEAMENTO DA INFORMAÇÃO

A qualidade da informação da REPI, nos três segmentos, para a maioria dos ouvintes - $73,77 \%$ - é excelente $(22,95 \%)$ ou ótima $(18,03 \%)$ ou boa $(32,79 \%)$, contra $24,79 \%$ de ouvintes que consideram seu nível regular e $1,64 \%$ que a consideram ruim. Esta "aprovação" está assinalada em colocações variadas, com realce para as músicas, os noticiários/atualidades, os entretenimentos, a ponto de alguém dizer: "... ela mescla utilidade prática, informação, programação musical local e regional", e outros complementarem: "... pelo menos é bem melhor que as outras..."; "tá mais povão, é AM mesmo".

Estes números apoiam a confiabilidade na REPI, externada por 78,69\% dos ouvintes, independente do local de moradia, em contraposição a cinco ouvintes que não se manifestaram, e 13,11 \% que desconfiam das notícias veiculadas, alegando que a rádio "... deixa muito a desejar nas verdades" ou "... as notícias (...) continuam parciais e tendenciosas (...) pois há manipulação do governo". Decerto, esse vínculo governamental, reconhecido por 44 dos pesquisados, pouco interfere no grau de confiabilidade dos ouvintes, e até mesmo na avaliação do objetivo educativo, uma vez que os três únicos ouvintes que mencionam essa função, o fazem de forma simplista: " a REPI tem objetivo didático e cultural"; "... diferente das outras, ela puxa um pouco para o lado educativo, que é importante"; "ensina muito às pessoas".

Essas e outras falas dos entrevistados e a análise dos scripts e da gravação de programas, levam a crer na concepção ingênua dos ouvintes, 
no sentido de, domesticadamente, contrariando Freire (1988), se transformarem em "vasilhas", "abarrotando-se" de mensagens, sem, porém, assumirem uma postura crítica, indispensável à análise do conteúdo e, principalmente, da proposta educativa da REPI. Sua programação, numericamente diversificada, é, no entanto, repetitiva no conteúdo e na forma e quase todos os programas são do gênero variedades, com nítido predomínio da função recreativa, sobretudo a programação musical. Adota-se o sistema de blocos musicais (três músicas), sendo que a média é de 10 músicas por hora, correspondendo a cerca de $50 \%$ do total da programação.

Seguindo-se a categorização de Fontecilla (1983), a função informativa — área jornalística - consta, basicamente, do "Jornal 800", com três edições, totalizando duas horas e trinta minutos, e do "Repórter 800" repetição de notícias do referido Jornal ao longo do dia - com a ressalva de que a parte noticiosa é produzida à base de "notas", com eventuais entrevistas, excluindo-se modalidades informativas como reportagens, debates, mesas- redondas. $O$ texto não tem uniformidade, embora prevaleça o modelo "manchetado" de noticiário da Rádio Jovem Pan (Porchat, 1989), que consiste em redigir as notícias em frases curtas, duas a duas, para serem lidas alternadamente pelos locutores. A primeira, a manchete, condensa o fato principal, seguida de tópicos que o sustentam, finalizando com a repetição da idéia central, reiterando-se a redundância como essencial à radiofonia, ainda que a REPI, sem adaptação à linguagem radiofônica, aproveite notícias difundidas pelos jornais teresinenses e pela TVE-PI, que seguem a estrutura de "pirâmide invertida", onde as frases perdem importância progressivamente. Isto decorre, em parte, da carência de fontes para subsidiar a produção dos programas, com a ressalva de que, pelo caráter estatal, o mecanismo de autocensura dos profissionais também contribui para a supressão de informações e, conseqüentemente, para a pouca criticidade dos ouvintes.

No caso das notícias oficiais, apresentam-se, visivelmente, formas de falseamento de que tratam a Comissão Internacional para o Estudo dos Problemas da Comunicação (1983), Enzensberger (1978) e Marcondes 
Filho (1989), sobretudo a personalização. Esta caracteriza-se pelo culto à personalidade e pelo destaque aos feitos de homens públicos "salvadores da pátria", "beneméritos do povo" —, em detrimento de uma visão contextualizada dos processos sociais, às vezes ocultando os legítimos sujeitos dos fatos sociais. A escuta atenta e a análise dos scripts provam que o grau de personalização é tão intenso, desde o início das notícias, que se dá, sempre, com um nome, um título, cargo ou órgão público: "O Governador"; "A Primeira Dama"; "A Secretaria de Educação". A política do destaque e da supressão da informação é outro recurso próprio das notícias oficiais — predominante na REPI —, com o fim de enfatizar o lado positivo dos atos do governo e ocultar o negativo.

Na mesma linha, aflora a fragmentação, em que os fatos são veiculados "... no seu aparecimento imediato e perde-se a dimensão de uma totalidade que os subsuma e os explique" (Marcondes Filho, 1989, p.41). É uma técnica mercadológica, imediatista e alienadora, usada, com frequiência, na REPI. Esta, inclusive, ocupa o espaço que as emissoras não-estatais destinam aos comerciais, para a propaganda oficial: promoções, eventos oficiais e anúncio de programas oficiais; pronunciamentos do governador em datas "especiais"; promoções personalistas, em que há sorteio de prêmios para quem acertar o nome completo de autoridades específicas... O espaço menor é reservado para as chamadas educativas, com ênfase na medicina preventiva, tais como do câncer de mama, da cólera etc. Vieira (1979), citada por Ortriwano (1985, p.59) é quem resume essas distorções e interferências, asseverando que o rádio é um "instrumento político que tanto pode servir à mudança como à manutenção de um Estado, das relações sociais, da própria liberdade individual e/ou coletiva. O mais eficaz veículo de informação torna-se um instrumento ideológico na medida em que seu controle e propriedade o transformam em arma. Arma que mobiliza, induz, liberta ou escraviza". Neste momento, retomando Habermas (1985), é preciso lembrar que a imprensa ao se comercializar torna-se manipulável e vulnerável. Na mesma linha de pensamento, Enzensberger (1978) assegura que, independente do regime político vigente, a informação jamais se constitui em atividade livre. A interferência 
política exercida sobre os MCMs é mais difícil de ser percebida, por sua sutileza e complexidade, ainda mais em se tratando do público-ouvinte da REPI, cujo perfil aqui delineado aponta para a falta de mecanismos críticos que propiciem uma ação libertadora.

Quanto à função informativa - área utilitária ou de serviços — inclui, basicamente, os quadros "Balcão de Empregos" e "Economia Popular", este último divulgando pesquisa diária de preços de produtos básicos. Ambos os quadros são reapresentados na maioria dos programas. Registrase, ainda, o "Plantão Jurídico", com esclarecimentos sobre temas gerais, e a transmissão ao vivo de eventos populares, ligados a ações governamentais, como sorteio de casas pela COHAB.

A análise do conteúdo educativo da programação da emissora é outro aspecto que merece atenção, visto ser a razão da existência da REPI, pelo menos em tese. Na prática, esse objetivo maior é relegado a um plano secundário, o que está explícito na programação ora veiculada. Salvo exceções, como o quadro "Boletim Cultural", da UFPI, repetido ao longo do dia, as demais emissões não apresentam características eminentemente educativas, mesmo na perspectiva da educação informal. Por carência de profissionais especializados e de infra-estrutura adequada (item RÁDIO EDUCATIVA DO PIAUÍ (REPI):IDENTIFICAÇÃO) O conteúdo educativo diluído ao longo da programação demanda planejamento, sistematização e adequação à linguagem radiofônica. Programas "populares", direcionados às comunidades rurais e da periferia, como "Vozes do Amanhecer" e "Brasil Caboclo" apresentam conteúdos alheios à realidade e um vocabulário muito técnico, que comprometem a compreensão das mensagens, como exemplificado neste scrípt: "Por apresentar um elevado teor de proteínas e sais minerais, a soja destinava-se à alimentação animal. No início da década de 70, ocorreu a grande expansão da cultura com os significativos retornos financeiros e o conseqüente aperfeiçoamento de máquinas e implementos. Já no final da década de 70 , a soja passava a ser uma das principais culturas brasileiras, com crescente desenvolvimento da indústria extrativa de óleo".

Não há, portanto, uma identidade da REPI como emissora educativa. 
Muito menos existe concatenação e sistematização do suposto conteúdo educativo que é diluído na programação, podendo-se compará-la a qualquer emissora de rádio AM, como foi registrado por um depoente. Como em Siqueira, Freitas, Haddad (1989), esta pesquisa mostra que a teleducação formal/informal, em termos de realidade local, e na forma como está estruturada, não se constitui em alternativa à escola. É preciso uma reformulação urgente de seus objetivos, para que a sociedade conheça a resposta à pergunta: Rádio Educativa do Piauí - a serviço de quê e de quem?

\section{Conclusões e recomendações}

CONCLUSÕES

As conclusões podem ser sintetizadas nos seguintes itens:

a) A audiência da REPI, no perímetro urbano de Teresina, é de 40,67\%, sobretudo graças à programação, citada por 34,43\% dos ouvintes, e aos noticiários, por $14,75 \%$.

b) A justificativa de maior peso, dentre os 59,33\% dos não-ouvintes, nos bairros adjacentes, centro e periferia, é a preferência por FMs $(25,84 \%)$ e a falta de tempo $(14,61 \%)$.

c) A freqüência de audiência mais comum, para os bairros adjacentes $(60 \%)$ e periferia $(54,55 \%)$, é a diária, em contraste com a força da audição ocasional $(53,85 \%)$, para o centro.

d) O público ouvinte da REPI, em termos globais, concentra-se na periferia $(54,10 \%)$ e tem o seguinte perfil: faixa etária de 20 a 29 anos $(40,98 \%)$; sexo feminino $(50,82 \%) ; 1^{9}$ grau incompleto e renda mensal familiar de até um salário mínimo, com índices iguais de 39,34\%; solteiro (75,41\%); católico (80,33\%); sem afinidade política definida (70,49\%); distribuído entre estudantes $(34,43 \%)$, jornalistas e radialistas $(13,11 \%)$ e outras profissões com menor representatividade. 
e) A programação da REPI, nos três locais estudados, é considerada por $73,77 \%$ dos ouvintes como excelente, ótima e boa, respectivamente.

f) Sem diferenças estatisticamente significativas nos bairros adjacentes, centro e periferia, 78,69\% do público-ouvinte afirma confiar na REPI, independente do seu vínculo governamental, aliás, conhecido por 72,13\% dos entrevistados.

g) As formas mais comuns de falseamento da informação radiofônica da REPI, ainda que identificadas raramente pelos pesquisados, são a personalização, o destaque e a supressão, e a fragmentação.

h) A função prevalecente da programação é a recreativa - área musical -, em detrimento das funções educativa e informativa.

i) Os programas de maior audiência são o "Rádio Movimento" (21,54\%), seguido de "Brasil Caboclo" e "Comando 800" com o mesmo número de pontos $(18,46 \%)$, sobretudo em face da programação musical, $(31,39 \%)$.

j) A participação dos ouvintes na programação dá-se em $22,95 \%$, mais na periferia $(71,42 \%)$, e o telefone é o meio mais comum de participação $(85,71 \%)$.

\section{RECOMENDAÇÕES}

Basicamente, são cinco as sugestões direcionadas a técnicos e administradores da REPI:

a) Redirecionamento da política técnico-administrativa, buscando resgatar a função educativa, na linha formal ou não, mediante planejamento, sistematização e transparência de ações, em todo o contexto, inclusive na adequação da linguagem radiofônica.

b) Contato efetivo com o público-alvo, no sentido de atender às suas reivindicações e aos anseios, ampliando-o, quantitativamente.

c) Maior atenção à interferência de cunho político-econômico, a fim de combater as formas de falseamento da informação.

d) Reconstituição imediata da memória da emissora, como forma de consolidar sua atuação. 
e) Maior aproveitamento da instantaneidade e da simultaneidade inerentes ao rádio, mediante utilização ampla dos recursos da radiofonia moderna, como unidade móvel, entrevistas, reportagens, debates etc.

\section{Referências bibliográficas}

BAUDRILLARD, J. À sombra das maiorias silenciosas: o fim do social e o surgimento das massas. 2.ed. São Paulo: Brasiliense, 1985. 86p.

BERQUO, E.S. Bioestatística. São Paulo: EPU, 1980. p.129-140; Amostragem.

BORDENA VE, J.E.D. Teleducação ou educação a distância. Petrópolis: Vozes, 1987. 77p.

COMISSÃO INTERNACIONAL PARA O ESTUDO DOS PROBLEMAS DA COMUNICAÇÃO. Um mundo e muitas vozes: comunicação e informação na nossa época. Rio de Janeiro: FGV, 1983. 499p. p.94-130: A comunicação hoje.

ENZENSBERGER, H.M. Elementos para uma teoria dos meios de comunicação. Rio de Janeiro: Tempo Brasileiro, 1978. 148p.

FONTECILLA, M.E. Rádio educativo: um guia para programadores. Rio de Janeiro: Associação Brasileira de Tecnologia Educacional, 1983. 77p.

FREIRE, P. A educação libertadora. In: COUTO, H.H. do (Coord.). A educação como libertação. Brasília: UnB, 1988. 95p. p.13 28.

FUNDAÇÃO IBGE. Censo demográfico. Rio de Janeiro, 1991. 
HABERMAS, J. Do jornalismo literário aos meios de comunicação de massa. In: MARCONDES FILHO, C. (Org.). Imprensa e capitalismo. São Paulo: Kairós, 1985. p.141-158.

HORTA, J.S.B. Rádio e educação no Brasil. Revista Brasileira de Estudos Pedagógicos, Brasília, v.59, n. 131, p.454-468, jul./set. 1973.

LAGE, N. Estrutura da notícia. 2.ed. São Paulo: Ática, 1987. 64p.

LOPES, M.I.V. Pesquisa em comunicação. São Paulo: Loyola, 1990. $148 \mathrm{p}$.

MARCONDES FILHO, C. O capital da notícia. 2.ed. São Paulo: Ática, 1989. 188p.

MARCONI, M. de A., LAK ATOS, E.M. Técnica de pesquisa. São Paulo: Atlas, 1990. 231 p. p.37-56: Amostragem.

MOVIMENTO NACIONAL DOS RADIALISTAS. Manual do radialista. São Paulo, 1991. 48p.

ORTRIWANO, G.S. A informação no rádio: os grupos de poder e a determinação dos conteúdos. São Paulo: Summus, 1985. 117p.

PORCHAT, M.E. Manual de radiojornalismo Jovem Pan. 2.ed. São Paulo: Ática, 1989. 205p.

PRADO, E. Estrutura da informação radiofônica. São Paulo: Summus, 1989. 101p.

SILVA, C.E.L. da. Muito além do jardim botânico. São Paulo: Summus, 1985. 161p. 
SIQUEIRA, M.C. de P., FREITAS, M.V. de, HADDAD, S. O ensino supletivo - função suplência - no Brasil: indicações de uma pesquisa. Revista Brasileira de Estudos Pedagógicos, Brasília, v.70, n.166, p.346-370, set./dez. 1989.

VIGIL, J.I.L. Rádio Revista de Educação Popular. São Paulo: ALER, 1986. 72p.

Recebido em 23 de março de 1992

Maria das Graças Targino, mestre em Biblioteconomia e Documentação, é professora-adjunta da Universidade Federal do Piauí. Antônio Teixeira de Barros é mestrando em Comunicação Social pela Universidade de Brasília e redator da TV Educativa do Piaú́.

This article analyses the State of Piaui educational radio, utilizing the Critic Theory as a framework. It focuses on the size and kind of its audience, the educational contents of its programmes, and forms of informational deceitfulness. It is also confronted to the general brazilian educational broadcasting into the whole national broadcasting system.

Cet article fait Vanalyse de Ia Rádio Educativa do Piauí (REPI) à partir de l 'étude de son audience, type de public-auditeur, programmation etcontenu éducatifetmanièresdefaussètéde $l$ 'Information radiophonique sous Ia perspective de Ia Théorie Critique, en cherchant Ia mise en contexte de Ia radiodijfusion éducative aupanorama de Ia radiodiffusion brésilienne. 
Analiza Ia Radio Educativa de Piauí (REPI) mediante ei estúdio de su audiência, tipo de público-oyente, programación y contenido educativo yformas de falseamiento de Ia información radiofônica, en Ia perspectiva de Ia Teoria Crítica, buscando, aún contextualizar Ia radiodifusión educativa en ei contexto brasileno.

\section{Anexo - Audiência da Rádio Educativa do Piaú}

ROTEIRO DE ENTREVISTA

Esta entrevista tem o objetivo de estudar a audiência da Rádio Educativa do Piauí no âmbito da capital piauiense

Idade

[ ] abaixo de 15 anos

[ ] 15 a 19 anos

[ ] 20 a 29 anos

[ ] 30 a 39 anos

[ ] 40 a 49 anos

[ ] acima de 50 anos

Sexo

[ ] masculino

[ ] feminino

Escolaridade

[ ] $1^{\mathrm{e}}$ grau incompleto

[ ] $1^{9}$ grau completo

[ ] $2^{9}$ grau incompleto

\section{IDENTIFICAÇÃO}

[ ] $2^{2}$ grau completo

[ ] $3^{9}$ grau incompleto

[ ] $3^{2}$ grau completo

[ ] pós-graduação

[ ] sem instrução formal

Renda Mensal Familiar

[ ] até 1 salário mínimo (SM)

[ ]2a5s Ms

[ ] 6 a $20 \mathrm{SMs}$

[ ] acima de $20 \mathrm{SMs}$

\section{Estado Civil}

[ ] solteiro

[ ] casado

[ ] separado

[ ] viúvo

[ ] amasiado 
Profissão

Religião

Bairro de moradia

Afinidade política

\section{RADIODIFUSÃO}

1) Você ouve a Rádio Educativa do Piauí?

[ ] sim

[ ] não

Por quê?

2) Com que frequiência?

[ ] diariamente

[ ] semanalmente

[ ] quinzenalmente

[ ] mensalmente

[ ] raramente

[ ] outra

Qual?

3) Que programa(s) você ouve com mais freqüência?

1.

2.

3.

4.

4) Por que você escolheu esse(s) programa(s)?

[ ]locutor

[ ] conteúdo

[ ] duração

[ ] horário

[ ] programação musical

[ ] outro(s)

Qual(Quais)? 
5) Você considera a programação da Rádio Educativa do Piauí:

[ ] excelente

[ ] ótima

[ ] boa

[ ] regular

[ ] ruim

[ ] péssima

Por quê?

6) Você pratica alguma atividade enquanto está em sintonia com a emissora?

[ ] $\mathrm{s}$

[ ] não

Qual?

7) Você participa da programação?

[ ] $\operatorname{sim}$

[ ] não

Como?

[ ] por carta

[ ] por telefone

[ ] pessoalmente

8) Quantas horas você ouve rádio por dia?

Quanto tempo é dedicado à Rádio Educativa?

9) Você confia nas notícias veiculadas na Rádio Educativa do Piauí? [ ] $\operatorname{sim}$

[ ] não

Por quê?

10) Você sabe a quem pertence a emissora?

[ ] sim

[ ] não

A quem?

Obrigado! 